\title{
Observations of deglobalization against globalization and impacts on global business
}

\author{
Hag-Min Kim and Ping Li \\ Department of International Business and Trade, Kyung Hee University, \\ Seoul, Republic of Korea, and \\ Yea Rim Lee \\ International Commerce, Finance, and Investment, Kyung Hee University, \\ Seoul, Republic of Korea
}

\begin{abstract}
Purpose - This study aims to investigate current deglobalization against globalization and to hypothesize reasons and drivers of deglobalization. In addition, the study suggests an empirical model to test whether deglobalization exists in the world economy. The consequences of deglobalization are discussed.

Design/methodology/approach - Various measures for deglobalization are introduced for monitoring the deglobalization of a country, and statistical measures are reported. The research framework for deglobalization and empirical models are suggested. The relationship between deglobalization and globalization is being modeled using three KOF globalization indexes: economic, political and societal. This study used panel data from 1970 to 2017 for developed and developing countries to determine the degree of deglobalization.

Findings - Deglobalization has been found empirically since the global financial crisis. Deglobalization is estimated by the decreasing trend of import share in a country's gross domestic product and is influenced by manufacturing imports, country's income divide and political globalization. Both economic and societal globalizations have negative influence on deglobalization. Deglobalization is more apparent in developed countries than in developing countries, and the deglobalization trend will continue in diverse formats.

Research limitations/implications - This study limits the use of few variables to test the antecedents of deglobalization. Another study can be done to extend preceding variables and estimate the consequences of deglobalization, which may segregate the globalization effect. The international business executive should understand the complexity of deglobalization and consider business benefits and risks to be encountered.

Originality/value - This study used panel data from 1970 to 2017 for developed and developing countries to determine the degree of deglobalization.
\end{abstract}

Keywords Deglobalization, Globalization, Trade impacts, International business risks, Global value chain, Technology change

Paper type Research paper

\section{Introduction}

The global economy is facing new challenges, including overcoming the slow economy in the world and minimizing the risks due to a depressed world economy. Additionally, countries must manage international business and trade under the growing deglobalization circumstance. Globalization is the process of increasing interdependence and integration toward a world society. Deglobalization is the opposite context of globalization and is the

(C) Hag-Min Kim, Ping Li and Yea Rim Lee. Published in International Trade, Politics and Development. Published by Emerald Publishing Limited. This article is published under the Creative Commons Attribution (CCBY 4.0) license. Anyone may reproduce, distribute, translate and create derivative works of this article (for both commercial and non-commercial purposes), subject to full attribution to the original publication and authors. The full terms of this license may be seen at http://creativecommons. org/licences/by/4.0/legalcode

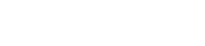


ITPD

4,2 process of diminishing interdependence and integration between certain units around the world, typically nation states.

Scholars argue that drivers toward deglobalization include trade imbalance, political pressure, populism, high unemployment rate and trade tensions between countries. The coronavirus disease pandemic has been pervasive during the first part of 2020, shrinking the global economy due to reduced movements of goods and services. Due to these circumstances, there is a high risk of the world economy to move into a depression.

However, history demonstrates that the cyclic phenomenon between globalization and deglobalization has appeared in the world economy. Free trade proponents promote international trade and business activities, whereas opponents want to protect assets and security from the problems or risks of globalization. Global shocks affect different regions of diverse magnitude. Some regions are particularly hard hit by global shocks, some are affected by smaller ranges and some appear to not be impacted at all (Van Bergeijk, 2017). From Trumpism to Brexits, there is a tendency for deglobalization to be centered on developed countries, which is not a new development, as the debate between globalization and free trade and deglobalization with trade protections continues.

The key research question is how the recent phenomenon of deglobalization differs from those of the 1930s and in 2008. Furthermore, it is important to study whether the current deglobalization trend will be more intense in the future. The coronavirus disease in 2020 makes the world economy more protective and increases barriers of goods and services and financial investments.

Regarding international business management and the current global value chain (GVC), determining the appropriate reconfiguration of GVC and business strategy is essential.

The literature related to deglobalization is limited, as the scholarship is at an early stage and works have focused on the conceptual studies by Stiglitz (2007). The literature shows that the antecedents of deglobalization came from economic factors only and later included political and social dimensions.

This study aims to investigate the current deglobalization. This study examines the historical cyclic pattern between globalization and deglobalization by Jones (2005), reviewing the ongoing debates in terms of origin, extension and consequences. Most western nations belonging to the Organization for Economic Co-operation and Development (OECD) countries support free trade and capitalism, and international trade and entrepreneurship have been key drivers of economic growth. After the financial crisis in 2008, the world faced the challenges of income inequality, populism of politics and new international political threats from. Globalized free trade is controversial in nonprofit organizations, because free trade with capitalism accelerated economic gaps between rich and poor, developed and underdeveloped countries. South Korea has put much effort into export-driven economic growth policies, and it has been successful. Most countries with high trade intensity face new challenges overcoming the pressures of deglobalization.

\section{Review of literature}

\subsection{Birth of deglobalization against globalization}

Globalization is highly connected with multinationalism and international economic integration. Globalization signifies the importance of standard procedures, free trade, international compliance and international investment. International organizations, such as the World Trade Organization (WTO), International Monetary Fund (IMF), United Nations Conference on Trade and Development (UNCTAD), were considered important for world trade and economy. However, criticism came out against globalism, due to inequality and unfairness became critical issues among trading nations. These brought about regionalism and has resulted in regional cooperation, like free trade agreements (FTAs), at the country 
level increasing. Additionally, regional integration agreements, such as the Association of Southeast Asian Nations (ASEAN), European Union (EU) and Comprehensive and Progressive Agreement for Trans-Pacific Partnership (CPTPP), reflect a deviation from multinationalism and globalism.

This reaction to globalization creates deglobalization, which can result back to globalization. Globalization and deglobalization have a cyclical competition throughout history. Jones (2005) indicates that the first global economy was from 1840 to 1929. Then, the depression and the First World War caused the first deglobalization from 1929 to 1979. During this period, the world suffered the Second World War, western nations worked to eliminate trade barriers and many countries became WTO members. The second globalized economy followed 1979 and continued until the global financial crisis in 2008. Distrust of financial systems and global companies caused nations to worry about inequality and the income divide. Even though international trade had grown the economy, powerful individuals as well as small-to-medium enterprises (SMEs) believed that they were not paid fairly. This captured the attentions of the public as well as politicians, and the crisis created a new pattern of deglobalization.

Stiglitz (2007) argued that developing economies were not growing at all and demonstrated that, through tariffs, subsidies, an over-complex patent system and pollution, the world was being both economically and politically destabilized. Therefore, an examination of incomplete markets could make corrective government policies desirable. This reflects the negative aspects of globalization. Since then, there have been several observations showing deglobalization.

First, import tariffs barriers have been strengthened by developed countries, and imposing tariffs has been a relatively easier policy for trade governance agencies. Specifically, the US Trump Administration imposed high tariffs on Korea, China and others who had enjoyed a trade surplus against the USA. Figure 1 show the safeguard and high tariffs in recent years.

Safeguard measures were infrequently used, and some governments used "gray area" measures to protect their industries. Beginning in 2014, total number of safeguard cases worldwide decreased, but it has shown an increasing trend again since 2018. On May 10, 2019, the USA increased import tariffs from 10 to $25 \%$ on US $\$ 200 \mathrm{bn}$ of Chinese goods. A trade war between the world's two largest economies was initiated.

Second, non-tariff barriers (NTBs) have been imposed using different methods. NTBs refer to restrictions that arise due to difficult or costly prohibitions, conditions or specific market requirements for the import or export of products. NTBs include the unfair and

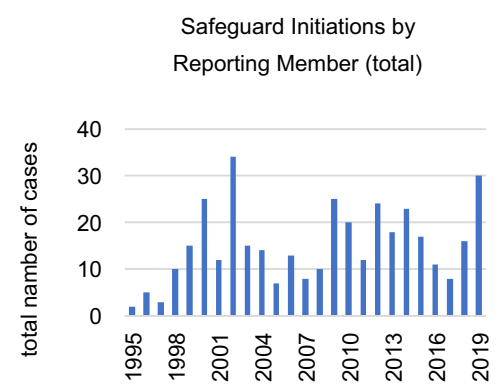

Source(s): WTO

(https://www.wto.org/english/tratop_e/safeg_ e/safeg_e.htm\#statistics)
Observations

deglobalization

85

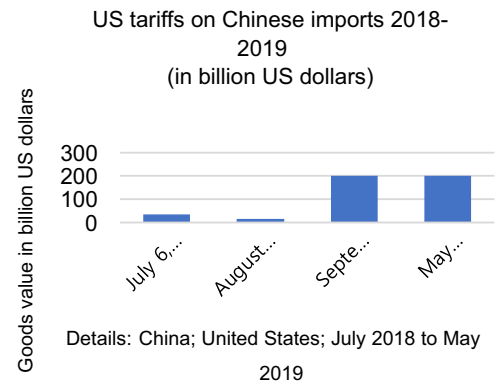

Source(s): BBC, Statista2019
Figure 1. Safeguard and US tariffs issue 
ITPD

4,2

86

improper application of non-tariff measures such as sanitary and phytosanitary (SPS) measures and other technical transaction barriers (TBT). NTBs to trade can arise from import bans, general or product-specific quotas, "buy national" policies, over-valued currency, restrictive licenses, complex regulatory environment, import licenses, seasonal import regimes and the like.

Third, over the past decades, the global economy has tended to be structured around a $\mathrm{GVC}$, which is responsible for a large percentage of global trade, production and employment (Pla-Barber and Villar, 2019). GVC reconfigured world trade regarding participants and comparative advantages. Increasing value chains have been restructured in the world economy, fueling advances in living standards in emerging markets, while widening income inequality in developed countries (Dollar, 2001).

According to Bello (2004), there are 14 features in deglobalization: (1) production for the domestic market; (2) subsidies at the national level; (3) strong trade policy; (4) industrial policy including subsidies, tariffs and trade to strengthen the manufacturing sector; (5) longpostponed measures of equitable income redistribution; (6) deemphasizing growth but emphasizing upgrading the quality of life; (7) power and transportation systems transformed into decentralized systems based on renewable sources; (8) healthy balance maintained between the country's carrying capacity and the size of its population; (9) environmentally congenial technology; (10) a gender lens to ensure gender equity; (11) strategic economic decisions to the market or to technocrats; (12) civil society monitoring and supervising the private sector and the state and a process that should be institutionalized; (13) the property complex transformed into a mixed economy; and (14) centralized global institutions replaced with regional institutions.

\subsection{KOF globalization index}

Another method for measuring deglobalization is the inverse of the globalization index. The opposite relationship between the two can support the notion that weak globalization results in strong deglobalization. The KOF index includes three items in terms of economic, political and social dimensions (Appendix 1). The globalization index shows a strong trend between 1990 and 2007. After 2007, the KOF globalization index shows a diminishing rate of growth. This reflects the fact that the USA and developed countries implemented trade barriers on imported products. In addition, social globalization does not grow much, except in Switzerland, The Netherlands and Belgium. The political globalization index continues to increase. As the KOF globalization index increases, economic growth shows a strong pattern (Figure 2).

This study interprets deglobalization as the slowness or declining pattern of the globalization index in the world. For example, economic globalization has not been apparent since 2008. The KOF economic index can be divided into trade globalization and financial globalization. Trade globalization has not been increasing, but de facto financial globalization has shown an increasing trend during the past few years. However, de jure financial globalization does not change. The de facto trade globalization has decreased since 2014, and world trade has been experiencing a downward trend. However, the trade disputes between the USA and China are difficult to measured.

Social globalization did not show an increasing pattern because personal interactions, such as tourism and immigration, have not increased, but the information flow such as patents, high-tech products and international data transfer has been increasing. However, political globalization shows an increasing trend (Figures 3-5).

\subsection{Deglobalization by imports share of the gross domestic product}

During the period 1880-2000, world trade shows a positive trend, except for the negative $12 \%$ in the 1930s. Also, during the period 1951-2008, the periods with negative growth rates of less 

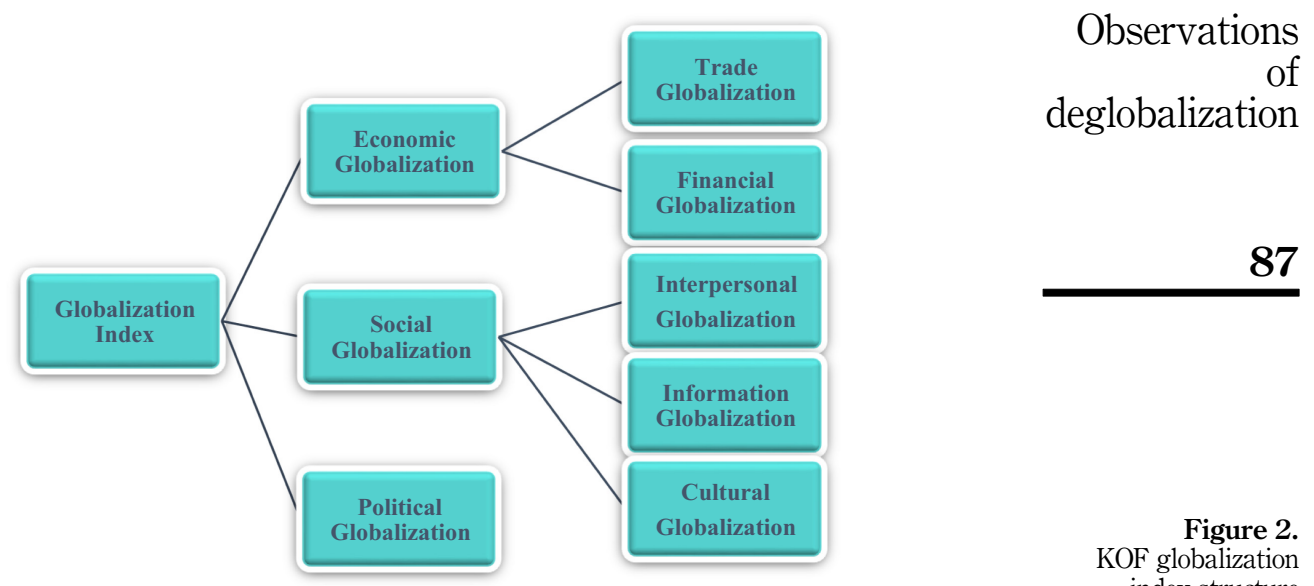

Source(s): KOF Globalization Index

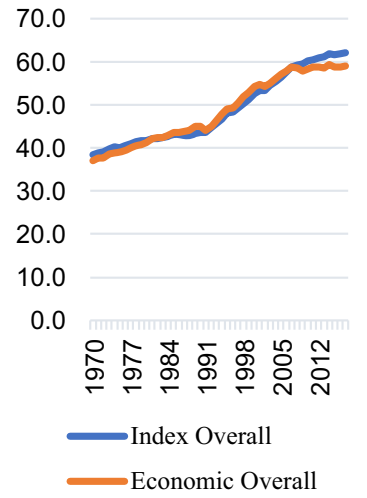

Source(s): KOF Swiss Economic Institute (https://kof.ethz.ch/en/forecasts-and-indicators/ indicators/kof-globalisation-index.html)

Figure 3. KOF economic globalization index from 1970 to 2017

than 7\% were 1958, 1972, 1980 and 1982 (Van Bergeijk, 2011). The world economy shows a slow growth trend after the financial crisis of 2008, and the world trade of G7 countries shows a trend of deglobalization. This is the opposite pattern of globalization. The trend of imports at the country level is a good indicator of the degree to which deglobalization proceeds in a country. Higher deglobalization means a country's imports are not increasing. Figure 6 illustrates the import share of goods and services as a percentage of the gross domestic product (GDP) in G7 countries.

Many reasons explain deglobalization, including continuously low unemployment in the world economy. The low unemployment problem in the world economy creates a job protection issue in one country, which protects the country from importing goods. It explains 
ITPD

4,2

88

Figure 4.

KOF social

globalization index

from 1970 to 2017

Figure 5.

KOF political globalization index from 1970 to 2017

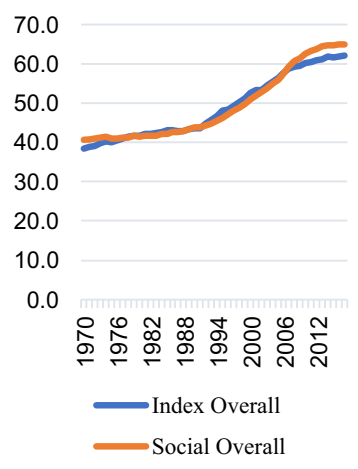

Source(s): KOF Swiss Economic Institute

(https://kof.ethz.ch/en/forecasts-and-indicators/ indicators/kof-globalisation-index.html)

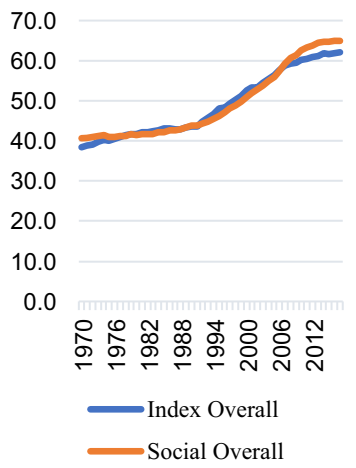

Source(s): KOF Swiss Economic Institute (https://kof.ethz.ch/en/forecasts-and-indicators/ indicators/kof-globalisation-index.html)

a country's promotion of reshoring policies, because companies returning to their original country may contribute to job creation. The second reason for deglobalization is the income divide problem. There is a high correlation of the income gap between economic entities involved in international trading and non-trading entities. This situation creates less support for international trade in society. There is also an unfairness issue about pay. An easy policy for overcoming this inequality is to implement high tariffs and NTBs for imported goods and services to trade-surplus countries. This trade protection is relatively new, because politicians of developed nations are concerned about protecting fair trade. If this protective policy receives social and political support, this new trade protectionism will strengthen deglobalization. The G7 imports of goods and services trends have not been increasing since 2008. Using the import share as a deglobalization variable could be controversial, but it is a good candidate.

Imports of goods and services represent the value of all goods and other market services received from the rest of the world. They include the value of merchandise, freight, insurance, 


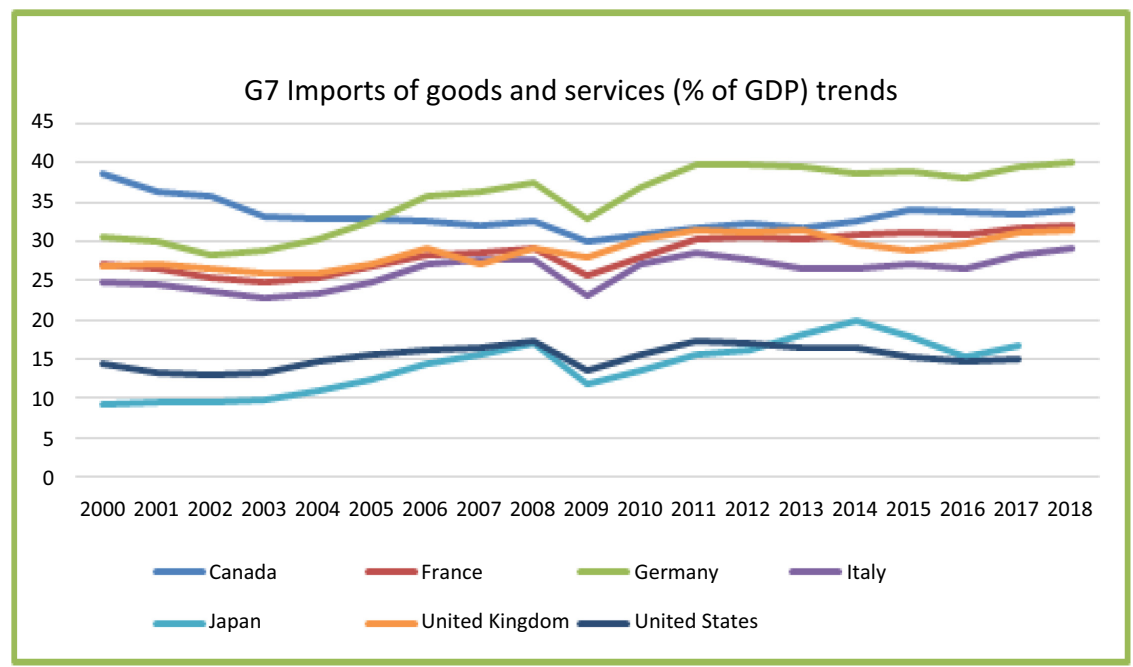

Source(s): UNCTAD STAT (https://unctadstat.unctad.org/wds/ReportFolders/reportFol ders.aspx)
Observations deglobalization

89

Figure 6.

G7 Imports of goods and services ( $\%$ of GDP) trends

transport, travel, royalties, license fees and other services, such as communication, construction, financial, information, business, personal and government services. They exclude the compensation of employees, investment income (formerly called factor services) and transfer payments. Table outlines scholarship supporting the use of this.

There are several reasons for using the import share to see the deglobalization trend. The import share is essential for production. Because of the GVC, not many countries would provide the raw materials to complete the whole production (Van Bergeijk, 2019). The main drivers of exports include the import demand of trading partners and the imposition of tariff, NTBs or protectionism in other countries show the degree of protectionism.

\section{Hypotheses, models and results}

H1. Deglobalization begins when the drawbacks of globalization are perceived in national society. Globalization started from economic motivations to see opportunities and to escape the risks from the protection, then came back to society with political concerns of national society, which resulted in de-globalization, and deglobalization started from political globalization, which has been shown in world society.

The first conjecture of this study comes from the fact that the deglobalization began because of the drawbacks of globalization. Globalization can be divided into three parts and the impacts of three dimensions fluctuate differently by country. For example, the US trade deficit against major trading countries has not been solved, even though the US government has put in much effort. This fact contributes to growing political concerns for the public that unemployment or offshore manufacturing is closely related to increasing imports by China, South Korea and other countries. The unemployment issue is a good target for politicians. Therefore, the political factor directly influences deglobalization of a country. 


\section{ITPD}

4,2

\section{0}

$\begin{array}{lll}\text { Authors } \quad \text { Methods and data } & \text { Findings }\end{array}$

Dreher (2006) Experienced analysis is made of sub-indexes configured to measure a single dimension using panel data from 123 countries between 1970 and 2000 , as well as whether the overall globalization index affects economic growth

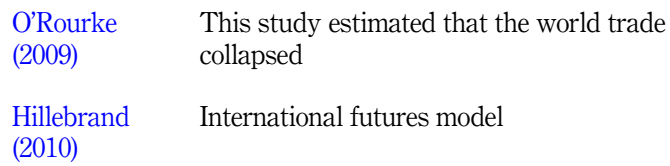

Van Bergeijk Import share of trade as globalization index (2017)

Flejterski Discussed the impacts of globalization and (2018) deglobalization on deferent areas of economy and society, such as costs and benefits, and winners and losers

Witt (2019) Qualitative research is used. Literature review and world statistics are used. Political factors of deglobalization are discussed using liberalism and realism
This study presents the globalization index, which deals with three main dimensions: economic integration, social integration and political integration. Globalization drives growth realistically. The dimensions most closely related to growth represent the actual economic flow and limitations of developed countries

In 2008/2009, the trade collapse was stronger than the decline that occurred in the similar phase of the Great Depression

If globalization halts or recedes, the results will be profoundly negative for most countries and most income groups

The study argues that an increase in the import share of the GDP would be a result of globalization

Both proponents and opponents agreed the phenomena that constituted globalization, but the assessment of those phenomena was diametrically different

Liberalism versus realism explains the paths of deglobalization. Liberalism reflects the failing of international organizations, and realism pushes the political hegemon of power in a country. Resulting opportunities exist in three areas of international business research: political strategies and roles of multinational enterprises (MNEs), GVCs and the role of the national context
Table 1.

Research findings for deglobalization study by scholars
H2. Deglobalization is more apparent in developed countries than in developing countries, because when the national economy is maturing, the political choice is to protect the resources within the governance compared to risks of international trades and investments.

The second conjecture is that deglobalization is happening more in developed countries than in developing countries. This is because the developed country's slow economy and world economic growth are not enough to create jobs, and they exacerbate entrepreneurship in the mature economy. Then, the question is how the deglobalization will be persistent in two groups, including emerging markets. The global financial crisis in 2009 resulted in the economies of China and other countries in the emerging market provided opportunities to overcome the crisis. For example, if a country no longer has entrepreneurship for the future economy, more protectionism occurs, because people would rather choose this when alternatives have less risks under non-stationary periods.

H3. The income inequality or unemployment of one country creates the pressure of deglobalization, and political globalization contributes to deglobalization actions. However, economic inequality would not be resolved in a single dimension, because people make decisions based on different choices, beliefs or philosophies of their own freedom. 
The third conjecture is that income inequality in one country contributes to deglobalization. The Gini index shows the level of income inequality in one country. Therefore, a higher Gini index strengthens deglobalization. Income inequality contributes to deglobalization in both developed and developing countries, because these countries usually have a large income divide.

\author{
of \\ deglobalization
}

H4. Worldwide, uncertain risks, such as the coronavirus pandemic in 2020, will exacerbate the speed of deglobalization to protect safety, because it is easy to control internationally moving items such as goods, services, investments and data contents.

The final conjecture is that the coronavirus pandemic in 2020 will exacerbate the speed of the deglobalization trend. The global pandemic crisis causes every country to make decisions in terms of the international movement of goods and services. It is obvious that less international trade results in a slower economy throughout the world. Therefore, important remedial actions should be taken in all countries. Therefore, political economic assessments become critical, so economic, political and social factors should be considered together.

Figures 7-9 are scatter plots and the ordinary least squares (OLS)-fitted lines showing the relationship between the dependent variable of import share of the GDP and each independent variable in the model. For all countries, a negative impact between the import share of GDP and the manufacturing import share of product imports is expected. There is no correlation between the import share out of the GDP and the Gini index for all countries. However, for developed countries, the Gini index can influence deglobalization. It is expected that there is a positive correlation between the import share of GDP and the KOF economic globalization index, the KOF social globalization index and the KOF overall globalization index. It is expected that there is a negative correlation between the import share of GDP and the KOF political globalization index. In developed and developing countries, the results will be similar.

\title{
3.1 Empirical model
}

An empirical model is used for testing the significance of economic, social and political globalization on deglobalization. The variables used for this model are KOF indexes as independent variables and the national import share of GDP. This study uses panel data from 1970 to 2017 for developed and developing countries to determine the degree of deglobalization. The research model is given as follows:

$$
\begin{aligned}
\operatorname{Imtg}_{i t}= & \beta_{0}+\beta_{1} \operatorname{Manuim}_{i t}+\beta_{2} \operatorname{gini}_{i t}+\beta_{3} \operatorname{ecogl}_{i t}+\beta_{4} \operatorname{sociogl}_{i t}+\beta_{5} \operatorname{poligl}_{i t}+\in_{i t} \\
& \operatorname{Imtg}_{i t}=\beta_{0}+\beta_{1} \mathrm{GDP}_{i t}+\beta_{2} \operatorname{Manuim}_{i t}+\beta_{3} \text { gini }_{i t}+\beta_{4} \text { overalglo }_{i t}+\epsilon_{i t}
\end{aligned}
$$

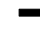




\section{ITPD}

4,2

92
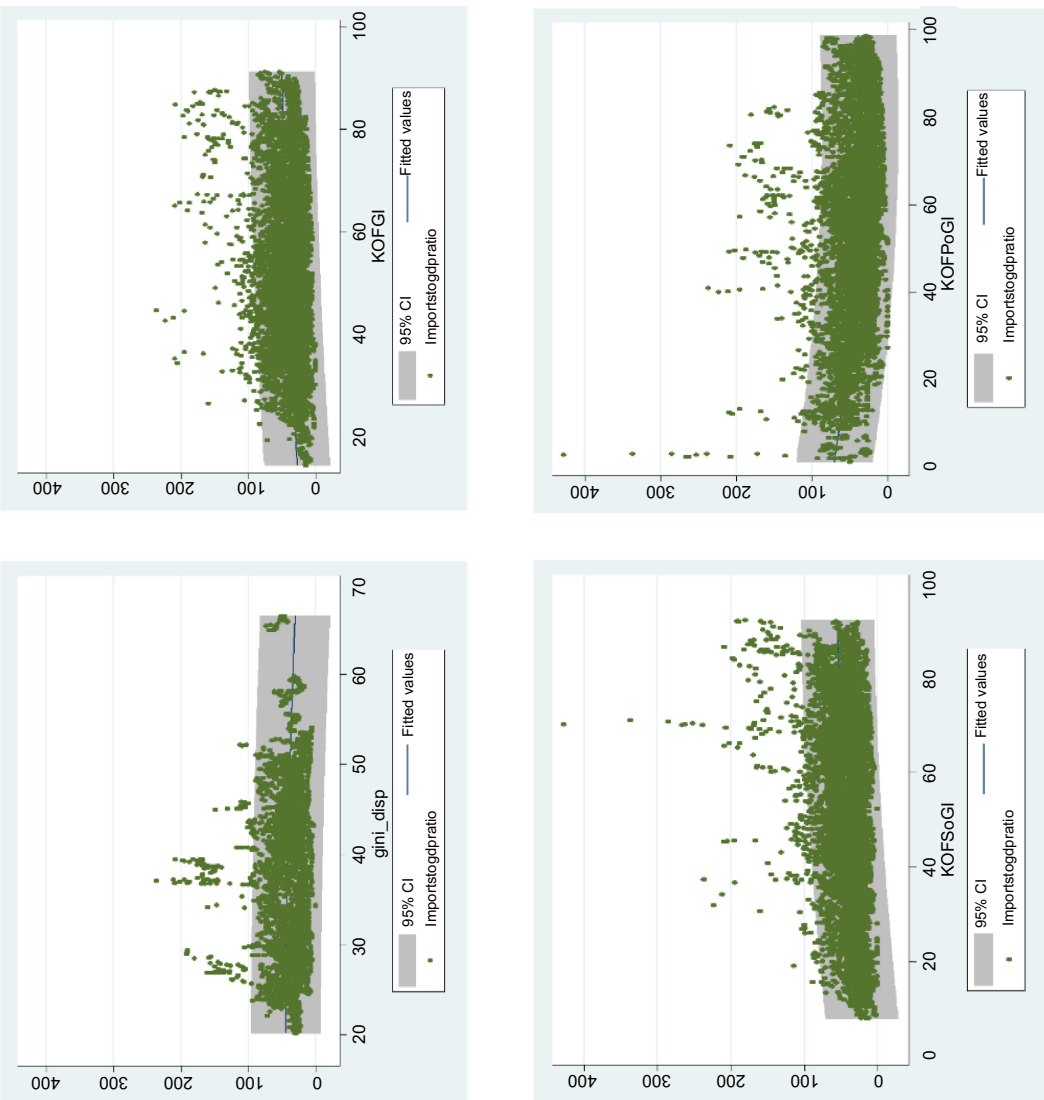

Figure 7.

Scatter plots and OLS
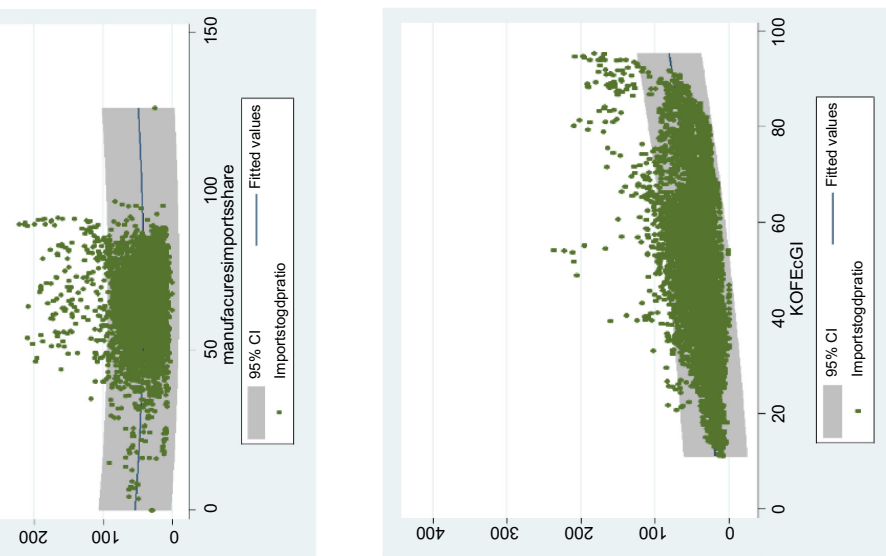

fitted (overall) 


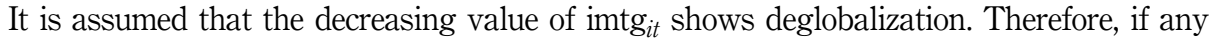
estimated coefficients for $\beta_{1}, \beta_{2}, \beta_{3}, \beta_{4}, \beta_{5}$ in equations (1) and (2) show a negative value, then the variables with negative coefficients contribute to deglobalization. If the negative influence of the variables suggested is found, it explains the contribution to deglobalization. That data are classified into two groups, developed and developing countries, using the classification standard of the United Nations World Economic Situation and Prospects 2019. After classification, countries without sufficient data were excluded from the analysis. Our hypothesis is that the deglobalization of developed countries is stronger than that of developing countries.

In this study, the likelihood-ratio (LR) test was performed to verify heteroscedasticity, and the Wooldridge test was performed for the autocorrelation test. As a result, both heteroscedasticity and autocorrelation exist. Considering heteroscedasticity, autocorrelation and correlation between end variables and error term (endogenous), we used the generalized least squares (GLS) analysis method. The STATA 14.0 statistical program was used for analysis. The globalization index was first introduced by Dreher (2006). Globalization is defined as a process of producing and improving interdependencies between countries through the integration of national economies, cultures, technologies and governance. The higher the index, the greater the globalization, and vice versa. The KOF Swiss Economic Institute reported countries' globalization index from 1970.

Globalization has been conducted in various forms of trade agreements, including bilateral and regional agreements. This reflects the level of international interdependence in all sectors, including economics, society and politics. This has led to the formation of an international regime globally, leading to the organization of cooperative organizations of domestic and foreign groups and intensification of mutual exchange. However, with some countries deglobalizing, the complexity of international infrastructure and trade order is increasing.

\subsection{Analysis results}

Table 3 shows the descriptive statistics for the panel data from 1980 to 2017. The average proportion of imports to GDP is $42.7 \%$, and the maximum value is $236.69 \%$. The average proportion of manufacturing imports is $65.76 \%$, with a minimum of $3 \%$ and a maximum of $126.32 \%$. The average Gini index is $38.33 \%$. Among the three global indexes, the political index gap shows the largest range (i.e. from $1.19 \%$ to $98.58 \%$ ).

Table 4 shows the empirical results of the models for equations (1) and (2). The results are classified by (1) overall, (2) developed and (3) developing countries. The results indicate that

\begin{tabular}{|c|c|c|c|}
\hline Variables & Variable definition & Data source & \\
\hline $\begin{array}{l}\operatorname{Imtg}_{i t} \\
\text { Manuimit }_{i t}\end{array}$ & $\begin{array}{l}\text { the import share out of GDP for country } i \text { at year } t \text {, } \\
\text { the manufacturing import share out of } \\
\text { prouduct imports forcountry } i \text { at year } t\end{array}$ & $\begin{array}{l}\text { World Bank WDI } \\
\text { World Bank WDI }\end{array}$ & \\
\hline $\begin{array}{l}\text { gini }_{i t} \\
\text { ecoglo }_{i t}\end{array}$ & $\begin{array}{l}\text { GINI index for country } i \text { at year } t \\
\text { the KOF economic globalization index for country } i \text { at year } t\end{array}$ & $\begin{array}{l}\text { SWIID } \\
\text { KOF Swiss Economic }\end{array}$ & \\
\hline sociglo $_{i t}$ & the KOF social globalization index for country $i$ at year $t$, & $\begin{array}{l}\text { KOF Swiss Economic } \\
\text { Institute }\end{array}$ & \\
\hline poliglo $_{i t}$ & the KOF political globalization index for country $i$ at year $t$ & $\begin{array}{l}\text { KOF Swiss Economic } \\
\text { Institute }\end{array}$ & Table 2 \\
\hline overallglo $_{i t}$ & the KOF overall globalization index for country $i$ at year $t$ & $\begin{array}{l}\text { KOF Swiss Economic } \\
\text { Institute }\end{array}$ & $\begin{array}{l}\text { Variables definition } \\
\text { and data source }\end{array}$ \\
\hline
\end{tabular}




\section{ITPD}

4,2

\section{4}

Figure 8.

Scatter plots and OLS fitted (developed countries)
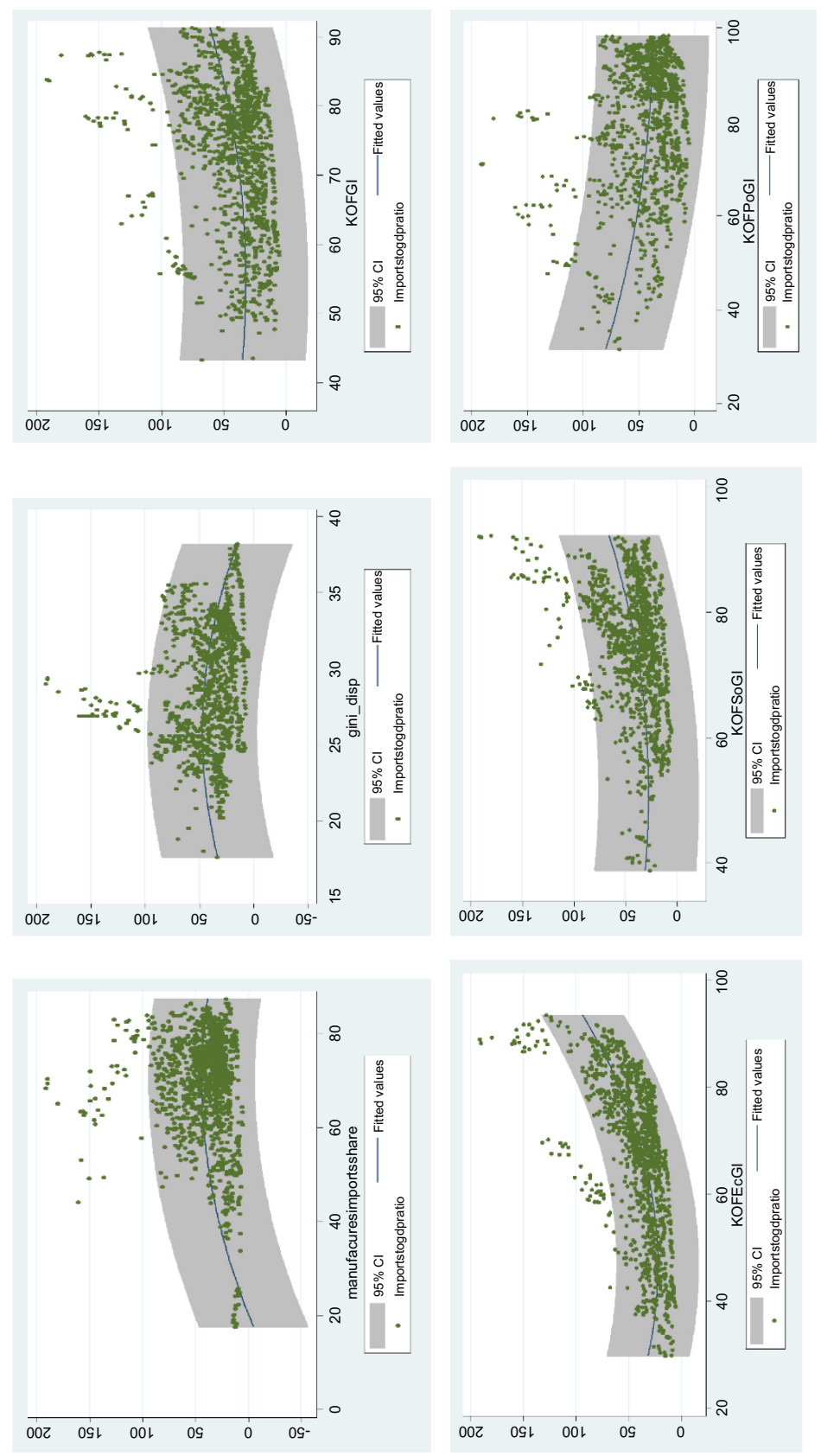

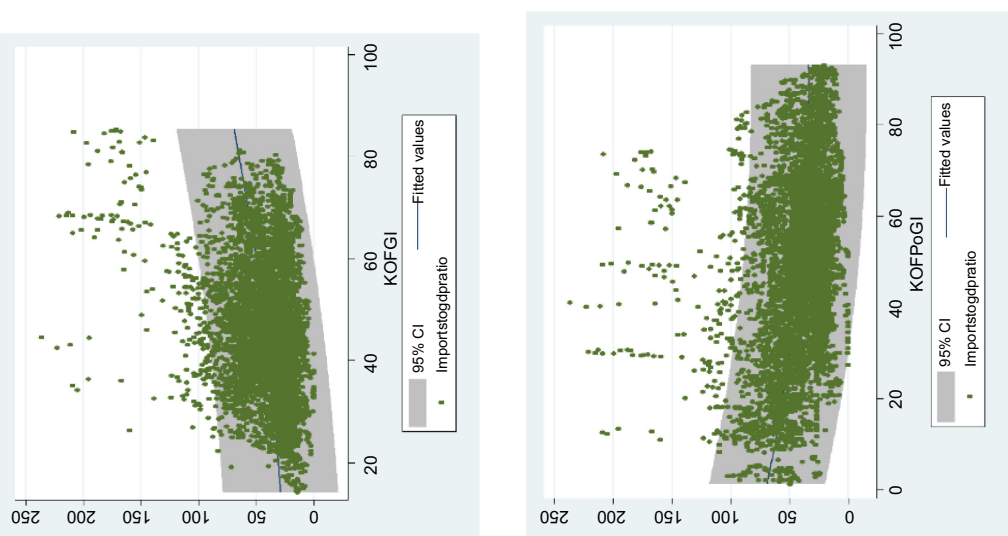

Observations
of
deglobalization
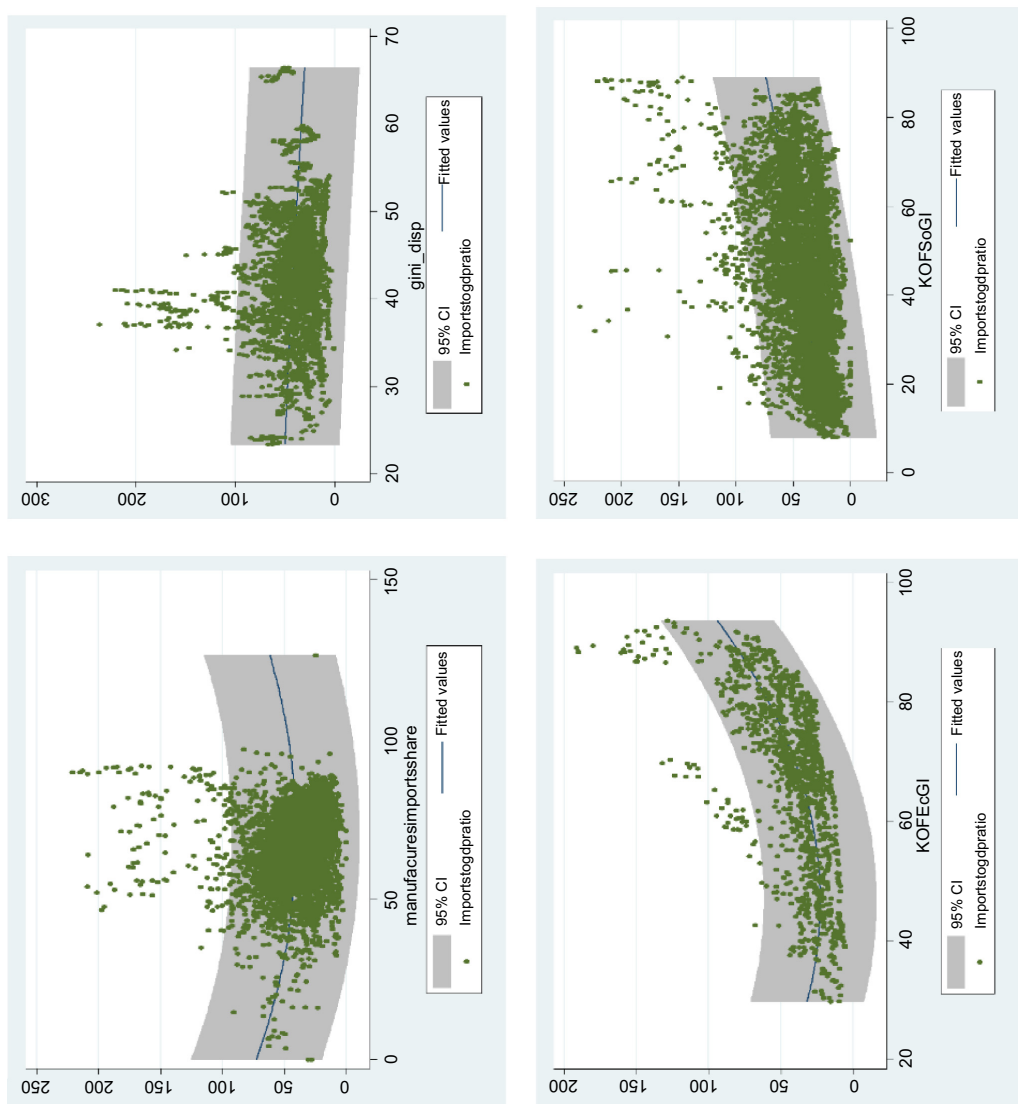

Figure 9. Scatter plots and OLS fitted (developing countries) 
ITPD

4,2

96

for all three groups, if the manufacturing import share increases, the weight of imports contributing to the GDP decreases. All estimates show negative values, which demonstrate evidence of deglobalization, and developed countries show stronger deglobalization than developing countries.

The Gini index for income inequality shows negative estimates for both developing and developed countries. However, the overall value is positive, because countries increase the manufacturing share when income inequality increases. This may reflect a reversed U-shaped curve for manufacturing import tardiness with income inequality level. Middleclass countries or household groups still import manufacturing goods for production or consumption.

The globalization index explains different contributions to manufacturing imports share. Overall, globalization contributes to an increase in manufacturing import shares. Both economic and social globalization have positive influences on manufacturing imports. However, political globalization has a negative effect on manufacturing imports. This has two implications.

First, political globalization has a negative impact on manufacturing imports share, because both developed and developing countries pay attention to manufacturing imports when the country is more globalized. Therefore, political globalization has a negative influence on deglobalization, and multinational trade or exporting should have the capacity to monitor regional political issues. The second implication is that political globalization is a controversial issue, because open countries do not necessarily mean openness of manufacturing imports. This means that the social attitude toward globalization is a mix of economic and political considerations.

In addition, as found in this study, income inequality consistently contributes to the birth and growth of deglobalization. Therefore, a trade policy to strengthen the income equality should be enacted. One way of doing this is to promote SMEs to be more involved in the GVC.

\subsection{Consequences of deglobalization}

This study uses the change in manufacturing import share to test deglobalization significance. Other research constructs for estimating the results of deglobalization are possible. Previous scholars suggest (1) import tariffs, (2) NTBs, (3) decrease in exports, (4) reshoring policy and (5) GVC reconfiguration. The results of deglobalization will be apparent at all country, firm and consumer market levels. The consequences of deglobalization actions can be found in many areas, and they will occur comprehensively.

The results of the analysis found that the political globalization index had an important effect on deglobalization. In this study, the role of the government and the state, which has not been discussed relatively, is more important, while previous research has focused mainly on economic aspects, including international trade and finance. Anthony Giddens (1999) said that the trend of globalization can be found everywhere in society, including business, politics

Table 3.

Descriptive statistics results

\begin{tabular}{lccccc}
\hline Variable & Observations & Mean & Standard deviation & Minimum & Maximum \\
\hline Imtg $_{i t}$ & 7,189 & 42.689 & 26.0067 & 0 & 236.391 \\
Maxuim $_{i t}$ & 6,047 & 65.7567 & 12.4184 & 0.0328 & 126.3198 \\
gini $_{\text {it }}$ & 4,865 & 38.3263 & 8.7691 & 17.5 & 66.5 \\
overall-glo $_{i t}$ & 8,100 & 50.1141 & 16.9918 & 14.2589 & 91.3134 \\
ecoglo $_{i t}$ & 7,955 & 49.4590 & 16.9918 & 11.1224 & 95.2853 \\
sociglo $_{i t}$ & 8,222 & 49.1294 & 21.9413 & 4.7967 & 92.2654 \\
poliglo $_{i t}$ & 82,222 & 52.0800 & 24.6863 & 1.1980 & 98.5865 \\
\hline
\end{tabular}




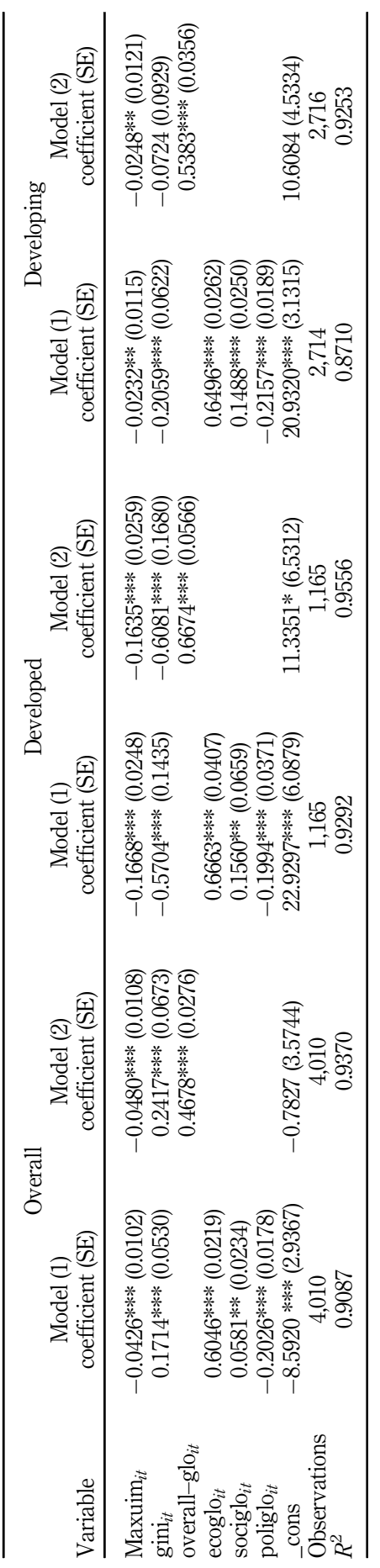
Observations deglobalization

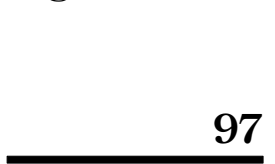

Table 4 Empirical analysis result 
ITPD

4,2

98

and academia. Due to increased uncertainty from the recent deglobalization, the importance of policy implementation and international political global activities, which are the areas of the state and government, is increasing. Therefore, to respond to deglobalization and implement policies effectively and efficiently, governments of each country need to devise strategies to meet new trends.

The emergence of deglobalization, such as the emergence of protecting trade led by the USA, the Brexit enforcement in the UK and the global crisis caused by the coronavirus disease, has spread, and the unstable and unpredictable risk of the existing international order is increasing. In this situation, the different institutional environments of the state can weaken or strengthen the role of globalization and deglobalization. The countries of the world interact economically, socially and politically to form a huge system. Deglobalization can be expected to hinder the growth of all countries, spread protectionism and increase uncertainty and conflict.

The results indicate these differences are stronger in developed countries, demonstrating an inequality in the political and global factors that affect deglobalization. To cope with the polarization of developed and underdeveloped countries and the resulting deglobalization, countries should pursue policies through international networks and cooperation, based on different economic and strategic interests. Immersive relationships to overcome crises and resolve conflicts and share trust between countries are expected to increase in importance.

A country's political and global aspects are closely related to its activities, including MNEs and SMEs. In particular, the GVC of MNEs is greatly influenced by uncertainty in international business. This requires rearrangement of the $\mathrm{GVC}$, which includes huge transaction costs. Additionally, companies influence their countries through corporate social responsibility (CSR). In the case of SMEs, national institutional support and protection also have a significant impact. Therefore, through the maintenance of the political and global aspects, the country can respond to deglobalization by strengthening support for international companies.

\section{Discussions}

The results of this study predict that more countries will be closing the doors for international business activities. The deglobalization trend is increasing, resulting in negative impacts on global business. In addition, the world society that is connected and would like to deal with the consequences of deglobalization. Deglobalization is not temporary and will be continuous. Countries will leverage the choice between globalization and deglobalization policies in their economy. The choice will be selective deglobalization, and the trade barriers will be bilateral. Protection issues, such as coronavirus risks, support deglobalization. The hurdle is to escape from the trap of a stagnant, non-trading economy. This is not an easy task, as deglobalization has a significant relationship with three dimensions of globalization: economic, societal and political issues.

We suggest several instruments for global business: (1) digital globalization expansion, (2) GVC recommendation and (3) elimination or decrease of international entrepreneurship barriers.

\subsection{Digital globalization expansion}

In the era of the Fourth Industrial Revolution, the movement of data between countries is the basis of digital globalization, making a digital platform an effective countermeasure of deglobalization increase. This can be applied to many business organizations at the national, business and individual levels. 
At the national level, it is possible to respond to deglobalization by establishing compatible e-governance for international data transfer through international cooperation. International consensus to solve digital trade barriers, such as data localization and intellectual property, is more important than ever.

At the business level, digital platforms change the economics of doing business across borders, reducing international and transactional costs. Globally, SMEs are becoming micromultinationals by connecting with overseas suppliers and providers using digital platforms such as eBay, Amazon, Facebook and Alibaba.

On the individual level, people are directly participating in globalization, using digital platforms to showcase their learning, job search and talent to build personal networks. For policymakers, a clearing agenda is needed to capture the global flows, and testing and learning approaches should be taken to keep up with the pace of innovation.

\subsection{Global value chain reconfiguration}

Deglobalization will change the current GVC positively and negatively for MNEs and SMEs. Many countries will monitor international business by imposing tariff and NTBs. A country can play a role in GVC and can participate in global flows in the new digital era. A country's political and global aspects are related closely to MNEs and SMEs. In a national context, corporate strategy and roles are important and interact with each other. An MNE's GVC is related to the SME's value chain. A country's political strategy determines the business environment, including location and risk reduction, which are important in terms of international business. The collapse of international rules and the proliferation of deglobalization create uncertainty in international business. This requires rearrangement of the GVC, resulting in significant transaction costs.

Conversely, MNE investments and trade activities impact a country's political components. MNEs' activities are important to a country's economy and internationally along the overall GVC chain, to influence international market changes, including national GDP. For developing countries, the rapid expansion of GVC has opened opportunities to participate in global markets. In the context, corporate social responsibility, even though the empirical analysis results of this study showed that economic factors do not directly affect deglobalization, other economic factors, such as trade and financial investment affect deglobalization through business activities of companies. Therefore, it could have acted through other factors or indirectly.

In the case of SMEs and MNEs, the global political environment is directly related to a company's operation. Many startup SMEs operate under governmental support and protection. For small companies with core technologies, support for institutional aspects, such as human resources and intellectual property protection for technological innovation, is essential. Therefore, through the maintenance of the political and global aspects, a country can respond to deglobalization by strengthening support for international companies.

\subsection{Elimination or decrease of international entrepreneurship barriers}

Disadvantages of entrepreneurship emerge when the external environment is uncertain and the return on investment decreases. In this state, companies do not make investments, take less risks and lose their leadership. Companies can be transformed into dark entrepreneurship through the process of recession, investment reduction, trade decrease, employment decrease and income decline. This means MNEs and SMEs are unable to trade internationally based on mutual trust, and they cannot respond to deglobalization. Therefore, national efforts are needed to enable entrepreneurs to create and develop stable international business relationships. 
ITPD

4,2

100

Selective deglobalization and local expertise are needed to effectively respond to influences from deglobalization. Regionalism enables multinationals and SMEs to coexist regionally and sustainably. Globalization and free trade force manufacturers to reduce production costs by moving or threatening to move. This can be one of the reasons for promoting deglobalization. Therefore, to effectively respond to deglobalization and coexist with regions, multinational companies need to selectively deglobalize, and SMEs need to increase corporate social contribution, especially by fostering and utilizing local experts.

Finally, international community leadership for sustainable actions is necessary. Companies can secure win-win situations by hiring local experts, employees from the community, fulfilling social responsibilities to the community and by operating a communityfriendly international community. It is possible to respond to deglobalization through stable business operations.

\section{Concluding remarks}

Due to the recent expansion of protectionism and the pandemic situation caused by the coronavirus disease, the world situation has become unstable, and research on deglobalization is increasing. Previous studies have focused on the conceptual study and arguments of deglobalization, and there are few empirical studies on deglobalization. This study suggests a model to determine empirical results and reasons for deglobalization at the national level.

In this study, the reduction of import share of the manufacturing industry in GDP was considered as a deglobalization variable. The study researched which of the three KOF's globalization index factors, economic, social and political, has the greatest impact on deglobalization. The results indicate that political efforts at the national level played a major role in responding to deglobalization. We sought methods to respond to effectively counter globalization at the national and corporate levels.

The main analysis results demonstrate that KOF globalization index (1980-2017) panel data were used to compare and analyze two groups of developed and developing countries. The political global index among the economic, social and political global indices had a significant negative effect on deglobalization. However, the economic and social aspects did not have a significant direct effect. There may be an indirect effect or "mediated and control effects with variables that are not included in this model," and further research is needed. Additionally, the negative influence of the political global index was greater for developed countries than for developing countries.

The results show the importance of the response to deglobalization on the political side of a country. To respond to deglobalization through the establishment of an effective and efficient national political system, digital globalization based on the Fourth Industrial Revolution technology, corporate GVC reconfiguration, international entrepreneurship based on mutual trust, selective deglobalization and local expertise training and efforts for international community leadership are necessary.

As the coronavirus disease spreads, protected trade is expected to increase, and economic and trade activities are expected to contract. From the perspective of MNEs, bold and swift decision-making is needed to eliminate growing uncertainty. This uncertainty includes direct factors like risk of infection spreading along the GVC and changes in various aspects of the business environment due to shrinking global economic activity. MNEs need to be alert to the changing environment and use entrepreneurship tactics to turn the crisis into an opportunity. The commitment and solidarity of participants are required across countries where GVC exists. In addition to MNEs, SMEs also need to exercise entrepreneurship to survive in a rapidly changing business environment. 
This study has limitations. With adequate data and other control variables sufficiently secured, the analysis with more countries can be conducted. Additionally, other indicators (quality of regulation, rule of law, etc.) have been provided, but effectiveness of government was not used in this study. Therefore, it is suggested that each research question and corresponding analysis and discussion of the data should also be conducted with this consideration.

\section{Observations of deglobalization}

\section{References}

Dollar, D. (2001), Globalization, Inequality and Poverty since 1980, World Bank, Washington D.C.

Dreher, A. (2006), "Does globalization affect growth? Evidence from a new index of globalization", Applied Economics, Vol. 38 No. 10, pp. 1091-1110.

Flejterski, S. (2018), "Globalization and deglobalization? Costs and benefits, winners and losers", Logistics and Transport, Vol. 39 No. 3, pp. 78-86.

Hillebrand, E.E. (2010), "Deglobalization scenarios: who wins? Who loses?", Global Economy Journal, Vol. 10 No. 2, pp. 185-197.

Jones, G. (2005), Multinationals and Global Capitalism: From the Nineteenth to the Twenty First Century, Oxford University Press, New York.

O'Rourke, K.H. (2009), "Government policies and the collapse in trade during the Great Depression”, in Baldwin, R. (Ed.), The Great Trade Collapse: Causes, Consequences and Prospects, p. 31, available at: www.voxeu.org/index.php?q=node/4267.

Pla-Barber, J. and Villar, C. (2019), "Governance and competitiveness in global value chains: a comparative study in the automobile and textile industries", Economics and Business Review, Vol. 5 No. 3, pp. 72-91.

Stiglitz, J.E. (2007), Making Globalization Work, WW Norton \& Company, New York.

Van Bergeijk, G. (2011), "On the brink of deglobalization: an alternative perspective on the causes of the world trade collapse”, Journal of Economic Literature, Vol. 49 No. 3, pp. 747-749.

Van Bergeijk, P.A. (2017), "One is not enough! an economic history perspective on world trade collapses and deglobalization”, ISS Working Paper Series/General Series, Vol. 628, pp. 1-23.

Van Bergeijk, P.A. (2019), Deglobalization 2.0: Trade and Openness During the Great Depression and the Great Recession, Edward Elgar Publishing, London.

Witt, M.S. (2019), "De-globalization: theories, predictions, and opportunities for international business research", Journal of International Business Studies, Vol. 50 No. 7, pp. 1053-1077.

\section{Further reading}

Abu-Bader, S. and Abu-Qarn, A.S. (2008), "Financial development and economic growth: empirical evidence from six MENA countries", Review of Development Economics, Vol. 12 No. 4, pp. 803-817.

Ahn, J.H. (2002), "Globalization and changes in the political economy of tripartism: a comparative study of Sweden, the Netherlands, and Austria", Korean Political Science Review, Vol. 36 No. 3, pp. 397-418.

Bellow, W. (2008), Deglobalization: Ideas for a New World Economy, Zed Books, London.

Campbell, D.L., Jacks, D., Meissner, C.M. and Novy, D. (2009), "Explaining two trade busts: output vs. trade costs in the great depression and today", Vox, September, Vol. 19.

James, H. (2017), “Deglobalization as a global challenge”, CIGI Paper No. 135, pp. 8-9.

Karunaratne, N.D. (2012), "The globalization-deglobalization policy conundrum. Modern economy", July, available at: https://ssrn.com/abstract=2096758. 
ITPD

4,2

102

O'Rourke, K.H. and Williamson, J.G. (1999), Globalization and History: The Evolution of a NineteenthCentury Atlantic Economy, MIT press, Cambridge, MA.

Piketty, T. (2015), "About capital in the twenty-first century", American Economic Review, Vol. 105 No. 5 , pp. $48-53$.

Reznikova, N. and Ivashchenko, O. (2018), "Projections of deglobalization in the contemporary international economic relations in the context of the paradigm of globalism”, No. 15, pp. 98-106.

Van Bergeijk, P.A., Brakman, S. and van Marrewijk, C. (2017), "Heterogeneous economic resilience and the great recession's world trade collapse”, Papers in Regional Science, Vol. 96 No. 1, pp. 3-12.

Warburton, C. (2017), "Trade treaties and deglobalization", Applied Econometrics and International Development, Vol. 17 No. 1, pp. 71-88.

\section{Appendix 1}

\begin{tabular}{|c|c|c|}
\hline $\begin{array}{l}\text { Economic } \\
\text { globalization }\end{array}$ & Actual flows & $\begin{array}{l}\text { Trade ( } \% \text { of GDP) } \\
\text { Foreign direct investment, stocks (percent of GDP) } \\
\text { Portfolio investment (percent of GDP) } \\
\text { Income payments to foreign national (percent of GDP) }\end{array}$ \\
\hline & Restrictions & $\begin{array}{l}\text { Hidden import barriers } \\
\text { Mean tariff rate } \\
\text { Taxes on international trade (percent of current } \\
\text { revenue) } \\
\text { Capital account restrictions }\end{array}$ \\
\hline $\begin{array}{l}\text { Social } \\
\text { globalization }\end{array}$ & Data on personal contact & $\begin{array}{l}\text { Telephone traffic } \\
\text { Transfers (percent of GDP) } \\
\text { International tourism } \\
\text { Foreign population (percent of total population) } \\
\text { International letters (per capita) }\end{array}$ \\
\hline & Data on information flows & $\begin{array}{l}\text { Internet users (per } 1,000 \text { people) } \\
\text { Television (per 1,000 people) } \\
\text { Trade in newspapers (percent of GDP) }\end{array}$ \\
\hline & $\begin{array}{l}\text { Data on cultural } \\
\text { proximity }\end{array}$ & $\begin{array}{l}\text { Embassies in country } \\
\text { Membership in international organizations } \\
\text { participation in UN Security Council Missions } \\
\text { International treaties }\end{array}$ \\
\hline $\begin{array}{l}\text { Political } \\
\text { globalization }\end{array}$ & \multicolumn{2}{|c|}{$\begin{array}{l}\text { Embassies in country } \\
\text { Membership in international organizations (FTA) } \\
\text { Participation in UN Security Council Missions } \\
\text { International treaties }\end{array}$} \\
\hline
\end{tabular}

Table A1.

KOF globalization index
Participation in UN Security Council Missions International treaties 
$\underline{\text { Developed countries }}$

\begin{tabular}{lllll}
\hline Australia & Austria & Belgium & Bulgaria & Canada \\
Croatia & Czech Republic & Denmark & Estonia & Germany \\
Greece & Hungary & Iceland & Ireland & Italy \\
Japan & Latvia & Lithuania & Luxembourg & Malta \\
The Netherlands & New Zealand & Norway & Poland & Portugal \\
Romania & Slovak Republic & Slovenia & Spain & Sweden \\
Switzerland & UK & USA & & \\
\hline
\end{tabular}

Developing countries

\begin{tabular}{|c|c|c|c|c|c|}
\hline Afghanistan & Albania & Algeria & Angola & Antigua and Barbuda & \\
\hline Argentina & Armenia & Aruba & Azerbaijan & Bahamas & \\
\hline Bahrain & Bangladesh & Barbados & Belarus & Belize & \\
\hline Benin & Bermuda & Bhutan & Bolivia & $\begin{array}{l}\text { Bosnia and } \\
\text { Herzegovina }\end{array}$ & \\
\hline Botswana & Brazil & Brunei Darussalam & Burkina Faso & Burundi & \\
\hline Cambodia & Cameroon & Cape Verde & $\begin{array}{l}\text { Central African } \\
\text { Republic }\end{array}$ & Chad & \\
\hline Chile & China & Colombia & Comoros & Congo, Dem. Rep & \\
\hline Congo, Rep & Costa Rica & Cote d'Ivoire & Cuba & Djibouti & \\
\hline Dominica & $\begin{array}{l}\text { Dominican } \\
\text { Republic }\end{array}$ & Ecuador & Egypt, Arab Rep & El Salvador & \\
\hline Equatorial Guinea & Eritrea & Ethiopia & Faeroe Islands & French Polynesia & \\
\hline Gabon & Gambia & Georgia & Ghana & Greenland & \\
\hline Grenada & Guatemala & Guinea & Guinea-Bissau & Guyana & \\
\hline Haiti & Honduras & Hong Kong, China & India & Indonesia & \\
\hline Iran, Islamic Rep & Iraq & Israel & Jamaica & Jordan & \\
\hline Kazakhstan & Kenya & Kiribati & Korea, Rep & Kuwait & \\
\hline Kyrgyz Republic & Lao PDR & Lebanon & Lesotho & Liberia & \\
\hline Libya & Macao, China & Madagascar & Malawi & Malaysia & \\
\hline Maldives & Mali & Marshall Islands & Mauritania & Mauritius & \\
\hline Mexico & $\begin{array}{l}\text { Micronesia, Fed. } \\
\text { Sts }\end{array}$ & Moldova & Mongolia & Montenegro & \\
\hline Morocco & Mozambique & Myanmar & Nepal & Nicaragua & \\
\hline Niger & Nigeria & Oman & Pakistan & Palau & \\
\hline Panama & $\begin{array}{l}\text { Papua New } \\
\text { Guinea }\end{array}$ & Paraguay & Peru & Philippines & \\
\hline Puerto Rico & Qatar & Russian Federation & Rwanda & Samoa & \\
\hline Saudi Arabia & Senegal & Serbia & Seychelles & Sierra Leone & \\
\hline Singapore & Solomon Islands & Somalia & South Africa & Sri Lanka & \\
\hline St. Kitts and Nevis & St. Lucia & $\begin{array}{l}\text { St. Vincent and the } \\
\text { Grenadines }\end{array}$ & Sudan & Suriname & \\
\hline $\begin{array}{l}\text { Syrian Arab } \\
\text { Republic }\end{array}$ & Tajikistan & Tanzania & Thailand & Timor-Leste & \\
\hline Togo & Tonga & Tunisia & Turkey & Turkmenistan & Table A2. \\
\hline Uganda & Ukraine & UAE & Uruguay & Uzbekistan & Name of countries for \\
\hline Vanuatu & Venezuela,RB & Vietnam & Zambia & Zimbabwe & analysis \\
\hline
\end{tabular}

\section{Corresponding author}

Ping Li can be contacted at: pingli3458@khu.ac.kr

For instructions on how to order reprints of this article, please visit our website:

www.emeraldgrouppublishing.com/licensing/reprints.htm

Or contact us for further details: permissions@emeraldinsight.com 